\section{Insect Pests of Stored Products}

The British Museum (Natural History) has recently issued a useful illustrated pamphlet (Economic Series No. 15) entitled "Common Insect Pests of Stored Food Products". Every year many inquiries relating to pests of this kind are received by the Museum. Usually the identification of such pests is not a matter of much difficulty, whereas the giving of advice on control measures is often very far from being easy and straightforward. The provision of this kind of advice is not properly the concern of the Museum staff, and, for this reason, the Trustees have welcomed the recent establishment of a Pest Infestation Laboratory by the Department of Scientific and Industrial Research and of an Infestation Branch under the Ministry of Food. The present booklet has been prepared at the request of these two organizations, and it aims at making easy the identification of the insects and arachnids commonly associated with stored products in Great Britain. The authors, Drs. H. E. Hinton and A. Steven Corbet, have avoided the use of any but the most elementary technical terms, so that the layman-apart from the entomologist-should be able to identify most of the pests that he is likely to come across. The pamphlet is obtainable, price $1 s$, through a bookseller.

\section{Protective Finishes for Scientific Apparatus}

THE June issue of the Journal of Scientitic Instruments consists mainly of three papers which constitute a symposium on "Protective Finishes for Scientific Instruments and Apparatus". In a foreword, Mr. A. J. Philpot, director of resenrch of the British Scientific Instrument Research Association, counters criticism of its value by pointing out the useful purpose served by "Any publication in which there is gathered together in a condensed form the available information on the various technical processes relating to a specific subject". In the present case, stronger emphasis would have been justified. Dr. Sutton's paper, for example, surveys dispassionately, and with the authority of unique experience, the relative merits of various protective treatments for different materials, pointing out the causes of corrosion troubles in instrumental work. It would be difficult, if indeed possible, to find the same information elsewhere in the literature. Dr. Bovey's survey of available anodic oxidation processes for aluminium alloys provides, in small compass, the essential information on their applicability and the characteristics of the films they yield. 'Review', 'summarize' and 'survey' are verbs of particular utility to a reviewer of technical literature. Unfortunately, they do not fit Mr. Wornum's paper on protective paints and varnishes. The most apt description is perhaps 'concise treatise', dealing, as it does, with the underlying principles of the processes involved in applying different types of coating as well as the properties and uses of these. Mr. Philpot may rest assured that there is little need to defend this symposium. It will be welcomed by all who use scientific instruments as well as those who make them.

\section{New Seismograph in Mexico}

A NUMBER of prominent American men of science, including Dr. Harlow Shapley, Dr. S. Chandrasekhar, Dr. Percy Bridgman and Dr. L. Don Leet, were present at the dedication of the new seismograph at the National Astrophysical Observatory at Tonan. zintla in Mexico by invitation of President Avila Camacho and the Governor of Puebla. The occasion was the first National Conference of Physics at Puebla. The seismograph, which was acquired by the State of Puebla, is a Benioff vertical-component instrument obtained through the National Research Council of Washington and the Harvard Seismological Station, and has been thoroughly tested by the Rev. Daniel Linehan, S.J., of Weston College (Earthquake Notes, 14, Nos. 3 and 4; June 1943). The instrument is expected to contribute to a large extent to the study of earthquakes in Mexico and the activities of sleeping volcanoes. The observatory where it has been housed is just east of the mountains Popocatepetl and Ixtaccihuatl. The installation appears to be timely, for a new volcano began eruption in the State of Michoacan, Mexico, on February 20, 1943. This is some two hundred miles west from Mexico City at an elevation of about 6,000 ft., near the town of Paricutin, which has had to be evacuated. Earthquakes are relatively frequent in many parts of Mexico, and a stronger one than normal occurred on February 22, 1943, at a point near the Pacific coast roughly 140 miles from the volcano in a direction $30^{\circ}$ east of south. The shock was felt strongly in Mexico City. There is no known connexion between the earthquake and the volcano just mentioned.

\section{Announcements}

ON the occasion of President Roosevelt's visit to Ottawa on August 25 the Chancellor of the University of London, the Earl of Athlone, on behalf of the Senate, conferred on him the degree of doctor of laws honoris causa. H.R.H. Princess Alice, Countess of Athlone, and the Prime Minister of Canada were present on the occasion; and the oration was read by Captain H. C. Best, professor of physiology in the University of Toronto.

Mr. A. W. LING, chief agricultural advisory officer, University of Bristol, has been appointed principal of the Seale-Hayne Agricultural College, Newton Abbot.

Prof. R. A. S. Macalister has resigned from the chair of Celtic archæology in University College, Dublin. $\mathrm{He}$ is succeeded by Prof. S. F. O'Riordan.

Mr. P. G. Hyslop has ceased to be a member of the Coal Commission of the Minister of Fuel and Power on the expiry of his term of office, and Lieut.Colonel J. A. S. Ritson has been appointed a parttime member of the Commission to fill the vacancy.

Tне British Rheologist's Club is holding a meeting at Loughborough College on September 18 at 10 a.m. The subject for discussion will be "Rheology in the Hosiery, Leather, Shoe and Allied Trades". Further information can be obtained from the Secretary, British Rheologist's Club, c/o Institute of Physics, The University, Reading.

A COURSE of three lectures and discussions on "Engineering Economics" will be given by Sir Frank Gill, director of the International Standard Electric Corporation and chairman of the Standard Telephones and Cables, Ltd., at the Institution of Electrical Engineers on Tuesdays at 5.30 p.m. beginning on September 21. These lectures are arranged by the University of London, and further information can be obtained from the Accountant, University of London, Senate House, Bloomsbury, London, W.C.1. 